\title{
Kirker i Aabenraa Provsti.
}

\section{Af Carsten Petersen.}

Den Tanke, at Herredsgrænserne kan have deres Betydning for Kirkebygningens Historie melder sig stærkere i Aabenraa Provsti. Vi opdager snart, at alle Kirker i Lundtofte Herred staar med et Klokketaarn ved deres Side. Videre ser vi, at alle Kirker i Sønder Rangstrup Herred har Taarne med Saddeltag (tvesidet Tag) og at alle Kirker i Rise Herred med en eneste Undtagelse er forsynede med et højt Spir. Undtagelsen er Hjordkær Kirke, som først blev bygget 1522. Varnæs er et eget Birk men regnes her med til Lundtofte Herred. Bov Sogn, som nu er indlemmet i Provstiet, hørte oprindeligt til Visherred syd for den nuværende Grænse.

Disse Forhold kan ikke være et Resultat af lutter Tilfaldigheder. Navnligt i Lundtofte Herred er Talen saa klar og bestemt, at et indre Fællesskab i Taarnbygningens Tid ikke staar til at nægte. Det lønner sig, at lade Øjet glide hen over disse mærkelige Taarne, som ikke findes nordligere paa den jydske Halvø. De fylder hele Lundtofte Herred, hvor der til Gengæld ikke er et eneste muret Taarn at se. Her har vi allerede et historisk Fingerpeg. Trætaarnene har ikke blot skullet være Klokkestabler men har tillige skullet erstatte et almindeligt Taarn. Dette Fingerpeg bliver kraftigere længere sydpaa. De to Herreder paa Midtryggen mellem Flensborg og Slesvig, Visog Uggelherred, har hvert en eneste Kirke med muret Taarn og Spir. Alle de ovrige Kirker havde Taarne af Tra, som Regel jyggede op ad Kirkens Vestende, der hvor det normale Kirketaarn plejer at staa. I det øvrige Land ligger 'T'retaarnene spredte fra Østersøen til Vesterhavet. De hører allesammen hjemme i Slesvig Stift. Nogle faa traffer vi paa $\Lambda \mathrm{ls}$ (forhen Fyens Stift) som senere skal omtales. Kirkerne i Lundtoft Herred hører altsaa afgjort med ind i dette Hele, er en Udløber af 
en kirkelig Kulturkreds syd for den nuværende Grænse og Jigger paa Linje med Kærherred, Vis- og Uggelherred o. s. v. Herredsgrænserne gør sig tydeligt nok gældende. Y'is- og U'ggelherred horer sammen og adskiller sig fra alle de andre. Lundtoft er helt selvstændigt. Der er altsaa et Slagtskab ud over hele stiftet som dog ikke hindrer et særligt Fællesskab inden for de enkelte Herreder.

Nu har der været Trætaarne andre Steder end netop i Lundtoft Herred, men enten kun forbigaaende eller i Forbindelse med murede Taarne. Præsten i Hellevad, den meget læste Forfatter Niels Heldvader beskyldtes for at have afbrændt et iille Klokketaarn paa Kirkegaarden, mens han fra sin side paastod, at det var sket ved Degnens Uforsigtighed. Taarnet kaldes med aaben ringeagt ein altes Türmlein. I Rise meldes om et Klokkehus 1704, ogsaa det forsvandt. Her siges udtrykkeligt, at det ikke kan undværes (1704), fordi Klokkerne da matte ophænges i Taarnet igen, hvilket Taarnmuren ikke vilde kunne holde til. Med andre Ord Klokkerne har hængt i Taarnet og er derefter blevne( af Nød) anbragt $i$ et Klokkehus. Vi vil traffe det samme andre Steder, f. Eks. i Hjordkær. Men i det mærkelige Lundtoft Herred eir der selvstændige Trætaame den Dag i Dag saa langt Herredets Grænser naar.

Heller ikke Billedet af Kirkerne i Rise og Sonder Rangstruy Herreder forstyrres derved, at enkelte af disse Kirker i et vist Tidsrum har haft et Klokkehus staaende ved siden. Alle de ene staaende Taarne af Sten er af aldre Dato og har rimeligvis sat deres Prog paa Herredet i lange Tider.

Det særegne ved Aabenraa Provsti - der dog først dannedes efter Kirkespaltningen og har varet underkastet mange Omreguleringer - er altsaa netop dette, at de til Provstiet horende Kirkebygninger er saa herredsprægede som intet andet sted i Sønderjylland.

\section{Kirkebygningen.}

De tre Kirker: Bedsted, Hellevad og Egvad liorte fra gammel Tid til Ribe Stift. Indtil Landsdelingen 1.34 lavile Iirkn- 
degnen dem i sit Provsti. Ii har derfor fundet dem i hans Regnskabsbog. Men denne Bog fortalte ikke om Laurentius Dithmer's Bedrifter, skønt den nævnte hans Navn. Han var Præst indtil $15 f i 4$ og tor vi tro Niels Heldvader, saa var det ham, der lod opbygge Spiret paa Egvad Kirke og desuden byggede et Sakristi ved Hellevad Kirke. Det var nu meget gjort af en Præst, men han var nok i Slægt med formuende Borgere i Tønder. For Resten var der i hans Dage en Sundhedskilde paa Præstegaardens Mark. Hvem ved, om ikke ogsaa den gav sit lidrag til Byggeriet.

Mere end denne Sundhedskilde i Hellevad betod sikkert det undergnende Billede af St. Hjalper i Klipler. Dfr var andre saadanne Billeder af den korsfastede Frelser i Landet, ogsaa med Kongekrone i Stedet for Taarnekronen. Men dette var undergørende, derfor var Kronen stærkt forgyldt, lerfor hang den $i$ et Sidekapel med Aabning ind til Kirken og derfor var denne Aabning spærret med et Gitter, thi det er klogt at holde Pilgrimmene paa Afstand fra Underet. Kirken i Kliplev blev en Valfartskirke $\Lambda t$ st. Hjælper ogsaa hjalp sin Kirke til Anseelse og Skønhed, kan der nappe være nogen Tvivl om. Det mest paafaldende ved deme Bygning er maaske dette, at Korpartiet rager et Stykke op over den avrige Del, medens det ved andre Kirker er lige omvendt. Mon ikke det skulde vare det undergørende Billede ved Siden af, som krævede hojere Hvalvinger og gav Midlerne til at bygge dem. Imidlertid ligger clisse Begivenheder forud for vort Tidsrum. Senere, efter St. Hjælper's Forlis, var det Slæagten Ahlefeldt, som tog sig af Kirken, og livad vi ser her, er mere præget af Herremændene end af Helgener. Den velædle Jomfru Birthe von Ahlefeld skarnkede 2000 M. lybsk (1580). Af Renterne kunde baade Vedligeholdelse og l'dsmykuing bestrides gennem lange Tiller. En Hest, som fortes efter Frederik v. Ahlefelds Lig maa ogsaa være tilfaldet Kirken. Den solgtes for $24 \mathrm{Rd}$.

Asbol var en af de minclste Kirker. I Slutningen af det 16. Aarhuntrede, da der af alle Kirker skulde betales Studenter- 
penge lod Fyrsten denne Kirke slippe for dens Fattigdoms Skyld, idet han lod de tre Sognekirker (de dre groten Karspelkarken) i Broager, Ullerup og Sotrup betale for den, Alse ist diese Capelle darmit verschonet - et Kapel kalder han den. Da alle dens Penge 1589 anvendes til Tagsten, maa Blyet have været den for kostbart allerede paa dette Tidspunkt. Det var ringe Dage i Asbøl. Hver Skilling, som blev tilovers ved Regnskabet blev forseglet in dem Kerckenbudelse (Kirkens Pung), saa var Fattigdommen under Laas og Lukke til næste Aar.

Bjolderup Kirke havde paa den Tid nogle Penge. En af Tømmermændenes Svende faldt ned fra Taarnet 1589, hvilket dog kun voldte en Udgift paa $1 \mathrm{Dl}$. Senere havde en Mester og tre Svende at bestille i 8 Uger (Klokketaarn). Ved Regnskabet var der endda ingen Smalhans. Præsteøllet blev drukket i Præstens Hus, en Tønde skummende tysk Øl (dudesch behr, Rostocker). Provsten og Amtsskriveren skæmtede med Præsten og Kaplanen; Kirkeværger og Degnen fik endnu Plads ved dette Bord, andre Godtfolk maatte solde de to Tønder Hjemmebryg op i Kroen. Provst og Amtsskriver tilligemed deres Køresvende overnattede. Næste Dag skulde der drikkes Rostocker $\emptyset l$ i et Nabosogn. Lidt fulde er de rimeligvis blevne tilsidst.

Felsted Kirke stod med sit slanke Rytterspir og kostbare Kobbertag hensunket i straalende Drømme om fremfarne Dage, da den var Domprovstens egen Kirke under Slesvigs Domkapitel. Disse Herligheder kom aldrig igen.

Sognekrøniken i Bov, der er meget velskrevet, fortæller, at Bov Kirke sandsynligt først ved Reformationen er blevet skilt fra Hanved. Vi har ingen samtidige Kilder, som kan belyse dette Forhold, og Kirkens Skæbne gennem det 16. Aarhundrede ligger i Mørke.

I det Hele er det saare lidt vi ved fra dette Aarhundrede. En Del Klokker støbtes. Michel Dibler i Flensborg satte Aarstal og et kraftigt Bibelsprog paa alle sine. Malerier har, som det nu er kommet for Dagen, smykket mange Kirkevægge, men Billedskærerkunsten laa et Stykke Tid stille. 
Før Kejserkrigen har Kliplev Kirke haft en stor Tid, vistnok en Frugt af Jomfru Birthe's rige Tilvendelse. Der brugtes Teglsten 1607 zum Glockenturm so gebauet. Samtidig blev Kirken malet af Hans Maler fra Flensborg. En ny Begravelse, et Sejerværk, en Mindetavle, en Prædikestol, en Døbefont o. a. er opført i disse Aars Regnskaber. Hans Maler dækkede Murpartiet i Koret med Syndflodens Historier. Heinrich Bildenschnider (Ringelingh) og Athoni Schnittker, begge fra Flensborg udforte betydelige Opgaver. Ogsaa udentil var Haandværkerne paa Færde. Der var Travlhed og der skabtes aabenbart af Overflod.

Der er endnu et Pusterum, inden vi hører Wallensteins Krigssignaler. Vi benytter det til at tale lidt on Oldemorstoft. Det er herfra, Bov Kirke fik sin Pryd, mens Dagene var lyse, og $\sin$ Hjælp, naar den faldt iblandt Røvere. Glemt er disse Hændelser ikke. Paa Indersiden af Korbuen er der malet to Rækker Navne med tilhorende Vaaben, paa den ene Side Mændene fra Olmerstoft m.ed en springede Hjort, paa den anden Side deres Hustruer. Iøvrigt læser man:

Renoviert 1669.

Renoviert 1766.

Dankbar gedenkt man hier der opferfreudigen Ahnen, die von Oldemorstoft Hülfe der Kirche gebracht.

Renoviert 1820. 18:0. 1851.

Den danske Indskrift, som siges at have været, stammede vel nok fra 1851; den har næppe kunnet krænke de gamle Herredsfogeder. Som første Ejer af Olmerstoft nævnes Henrik Jæger. Skattebøger fra 1483 opfører dog 3 Beboere og ingen Henrik Jæger. I alle Tilfælde var Gaarden i Begyndelsen af det 17. Aarhundrede delt $\mathrm{i}$ en Øster- og Vestergaard. Herredsfoged Lorens Nissen ejede den østre Part, og da Sognepræsten Joh. Conradus ogsaa nævnes som Ejer af Olmerstoft, maa hans Part have været den vestre. Præsten døde 1657. Kort før sin Død lod han male et Gravmæle, som blev anbragt i Koret, hvor det 
hænger endnu. Det maa siges at være et Mindesmierke af baade kunstnerisk og kulturhistorisk Værdi. Det er et udmærket T'idbillede, som fortæller en hel Del. Fire Personer, nemlig Præsten selv (Stifteren) med sin Hustru og to Sønner knæler paa blomstrede Puder omkring Korset. Mændene bærer sorte Talarer med hvide Halskraver og langt Haar bølgende ned over Skulderen. Kvinden barer en Hue og en bred Krave, derover endnu en Pibekrave, paa hvilken der ligger en dcblielt Halskæde ai Guld. Præsten selv har graat Fuldskag og holder Bibelen i sin Haand, de øvrige lægger Hænderne bedende mod hinanden. Fra den opstandne Kristus i Baggrunden faar Billedet Lys. Rammen er et Eksempel paa ganske ubehersket og vildt Barok, men aabenbarer vel sagtens noget af det, der levede $\mathrm{i}$ de afmalede Personer med de ellers saa rolige Ansigter. Der maa have været Velstand hos disse Præstefolk, men hvad deres Ord og Gerninger betød $\mathrm{i}$ og for selve Kirken kan jeg ikke sige noget om. Des mere er der at sige om Herredsfogeden. Da han lagdes i Graven, holdt Generalsuperintendenten Stefan Klotz i egen høje Person Ligtalen, og Talen blev trykt i Lybæk. Dette Areminde forslog dog ikke imod det Mindesmarke, Manden havde sat sig selv ved sine Velgerninger imod den gamle sognekirke. Fra 1626 og frem i Tiden skænkede han til Bov Kirke en ny Prædikestol (meget prægtig) et nyt Skjul over I aaben, en forgyldt Kalk, et nyt Fløjels Messeskrud, lod Prædikestol og Daah staffere, lod satte en forgyldt Knop og Fløj paa Kirken og anbringe et V'indue ved Prsedikestolen. Det meste af dette gik for sig uforstyrret af Kejserkrigen. Endnu efter hans Død omtales en stor Pengegave til Kirken, efter Svenskekrigen.

Ogsaa Bjolderup har før Kejserkrigen haft sin Byggeperiode. Der er betydelige Udgifter tho der Kerchen notdorff 1617-25. Blandt andet var Hans Maler (fra Flensborg?) i Arbejde baade med Alteret og andet. Præstekonen havde Besværet med Kosten til de mange Arbejdsfolk (der Pastorschen er Ungemack mit den Arbeitern). Tilsidst var der -- sikkert ogsaa til meget 
Besvær for Pastorschen - Visitats durch den generale Herrn Superintendenten den Ehrwürd. wohlachtb. und hochgelehrten Herrn Jacobum Fabricium (fra Slesvig) sammen med de nys udnævnte Provst Hr. Joh. Anchary.

Nicolaus Helvaderus beskylder sin Eftermand i Embedet (Hellevad) for at være en utro Kirkeværge. Han har set gennem Fingrene med Bønderne, saa de ikke betalte den fulde Tiende. Indtil nu har Kirken varet trkket med Kobber og Bly, men ned Tiden vil den ikke være istand til af sine Indkomster at bestride saa meget Straatag, saa den kan holdes under Tag, eller at man kan købe Messevin og Brød. Hr. Nicolaus har købt en Ligsten i Kobenlıavn, men Prasten vil ikke tillade, at den laggges paa halıs Faders Grav.

Saa blinker det over Flensborg Fjord. Kristian IV.s Armé er paa Hjemvejen efter Kampe ved Lutter am Barenberge. Bagefter konmer Wallenstein og hans Folk. I et Land, som flyder med Mælk og Honning, agter de at holde Gilde. Den 15. Sept. 16:27 hedder det i en Beretning, landede ved Holdnæs Færge kong. dansk Krigsfolk og udplyndrede hele sundeved, saavel Kirkerne som Sognefolket. Den egentlige Indrykning skete nu ikke over Holdnæs, men ad den gamle Hærvej. Hvad der laa i dens Nærhed, blev hjemsogt af Ven og Fjende. Men meget viskes ud paa Historiens Tavle. Hverken Bov eller Broager giver os Besked om Kirkernes Skiebne, ogsaa Ashal er tavs. Kliplev var forladt af baade Præst og Herrenand. In diesem Jahre (1627) weiln (Gott wende alles nach seiner väterlichen Barmherzigkeit hinwieder zum besten Stande) das Land mit Kriegsmagt überzogen. Ist nichts erfolget (ingen Indtagt).

\section{J. A. B.}

præceptor der .Jugendt auf Grauenstein.

Naste Aar var det det samme, ingen af Hen remandene var hjemme (keiner voll den Kirchenpatronen anheimbsch gewesen). I 1629 kunde endnu ikke holdes Regnskab wegen der grassie- 
renden Seuche. Kirken blev brøstfældig, Kalk og Disk maatte anskaffes. Mange Gaarde var øde.

Af Ulykkerne fik Uge Sogn dengang en Broderpart. Kirken og Byen med Undtagelse af 2 Gaarde gik op i Luer, efter Sigende stukket i Brand af Danskerne under Tilbagetoget. Et Øjeblik gjaldt det Sognets Eksistens, om at være eller ikke være i Fremtiden.. Kirken kunde ikke genopføres lige straks. Gudstjenesten holdtes paa en af de to forskaanede Gaarde, mens de ovrige Beboere søgte at genrejse deres ødelagte Hjem. Ogsaa for Kirkens Vedkommende blev Kampen taget op. En Indsamler drog afsted og bragte efter et Aars Omstrejfen $2^{1 / 2}$ Skilling netto l.jem, det øvrige var opslugt af Rejseudgifter (og af Landets Fattigdom). Saa var det Kirkeværgen Jes Hansen tog fat. Han havde nu længe nok set paa Ruinerne af det Kirkehus, som han var sat til at værge. Tiggergang maatte man gaa, men det gjaldt om at finde de rette Steder. Da Jes Hansen kom tilbage, efter at have udvidet Rejsens Radius til Holland, kunde Kirken i Uge genrejses. Et Taarn har den aldrig haft, men et Klokkehus stod for Branden vest for Kirken. Efter Branden hjalp man sig først med et tarveligt Stillads, indtil man fik et nyt Klokkehus 1685. Ogsaa dette stod oprindeligt paa et andet Sted men blev skruet hen paa den Plads, hvor det nu staar. Kristian III.s kostbare Bibel blev stjaalet af en kejserlig Soldat; men en forstandig Købmand i Aarhus afkøbte ham den og Sognet kunde indløse den 1642. Efter Sagnet var der engang baade Lobber og Bly paa Uge Kirke, men nu blev det til Spaan og Straa.

Byerne Aarslev og Nybøl i Nabosognet laa i Aske. I Kirkebyen (Hjordkær) stod Præstegaarden med nogne Mure. Kirken blev vel staaende men ikke urort; thi 1631 meldes der: "I denne forgangne Sommer hafuer den gandske almne vdj Jordkier Sogn aff djeris egne pending vdlagt til Kirckens bygnings forfremmelse» et Aars Tiende (ekstra).

Men Bjolderup Kirke delte Skæbne med Uge. Sammen med den havde de to andre Kirker i Rise Herred, Lajt og Rise, Navn 
af de bedste i Amtet. Sidst paa Aaret 1627 var den en rygende Tomt. Præstegaarden og Degneboligen ved dens Side fulgte den i Undergangen. Et halvt Hundrede Gaarde sank samtidigt i Aske. Men her kom Hertugen og andre gode Folk til Hjælp. Kjrkens udestaaende Kapitalier blev sagte op og for største Delen virkelig betalte. Hvor Pengene kom fra er ikke let at forstaa. Adskillige Bønder maa have haft noget gemt paa Kistebunden. Genopbygningen fuldendtes 1631 . Men først efterhaanden udstyredes Kirken i det Indre. Paa Døren stod i sin Tid: 1638.

Præstegaarden i Rise - hvorfor skulde ikke ogsaa den brænde? Den brændte. Maaske 100 Fag Hus. Med Kirken behøvede man ikke at gøre sig nogen Umage. Her havde, som vi saa, Lynet arbejdet i Forvejen, et levende Forvarsel om hvad der skulde komme.

Hvilket Syn for den, der vandrer op ad Hærvejen over Urnehoved og vender sig om for at se tilbage. I fire Kirkesogne ligger hele Landsbyer i Ruiner. Høje Kirketaarne er forsvundne. Tyske Eder lyder paa Vejene. Regiment efter Regiment samles til Appel ved Korsvejen. Langstøvlede Ben svinger sig over Hestens Ryg. Knyttede Næver rækkes i Vejret til Afsked og en bragende Forbandelse slynges ud over Landskabet med de ødelagte Byer. En Vogn kommer skumpende bag efter ad den trælsomme Vej. Belæsset er den med gammelt Jern af Dørhængsler og Murankere og med Bly af et Kirketag. De 4 Heste er tagne fra den sidste Bonde, som ejede noget i dette Sogn.

Rytterne drog nordpaa. Hvor vidt Flammerne fulgte med, ser vi ikke. Men en anden Følgesvend, Pesten, fulgte i al Fald med til Østerløgum, hvor den strakte 66 Personer til Jorden i 1627 og 74 i 1628, ialt 205 Mennesker. Ellers fortælles der fra dette Sogn, at en god Mand i Genner skænkede Kalk og Disk 1630 fordi de forrige ligesom Messeskrudet i Krigens Tid blev Kirken aldeles frarøvede. Andre kostbare Sager paa Alteret var ogsaa forsvundne.

Naturligvis spredtes Hærene bort fra de store Veje. I Var- 
nas ankom de kejserlige ved Mikkelsdags Tid 16i27 og forlod Sognet i Juni 1629. Wat des Pastors Mag. Peter sein güder Helanget hebben des Kaisers rütter Ehme in vorsehn Dage an Geldt Korn Proviant u. a. geranet und mit Gewalt affgezwungen -.. omtrent for 300 M. Præsten i Hellevad blev plyndret.

General Torstenson traadte nye Spor paa Elendighedens brede Vej. Men Genoprettere og Istandsattere var ogsaa tilrede. Den os allerede velkendte ubegribelig store og vedblivende Velgører Lorens Nissen paa Oldemorstoft gav Bov Kirke 400 M. i Forskud, sikkert til Udjævning af Svenskemes Bedrifter.

I Rinkenæs dukkede Svenskerne op ved Juletid 1643 og saa straks paa den smukke Kirke med dens nymalede Altertavle. Først rev de Blytaget af, det var Raastof til Kugler. Vinduerne lıavde ogsaa Bly, de gik sammme Vej. Derefter - saadan fortalles der - gjorde man Forsøg paa at stikke Bygningen i Brand, hvilket dog mislykkedes. Ved Fjendens Tilsynekomst nedgravede Præsten Alterkarrene i Jorden og tog Kar af Tin i Brug. Da Rytterne søgte efter Kirkens skatte og kun fandt. værdiløse Sager, blev de rasende og mishandlede den stakkels Prrst, som dog ikke forraadte sin Hemmelighed. Prastegaarden maatte brande. Sognefolket jagedes som Vildt. Fattigdommen blev saa stor, at man ikke ved egen Kraft formaaede at genoprette det faldne. Da skaffede Prasten ved Hjælp af sine formuende slagtninge i Flensborg et Laan tilyeje, saa den nødvendigste Istandsattelse kunde udføres. Til et nyt Blytag slog Nidlerne dog ikke til, den Herlighed var uigenkaldeligt forbi.

I Hjordkarr var Dorene lukkede; men Rytterne tog Vejen gennem Vinduerne. Soderup Port og Kaso Port splintredes og Dørene brændtes. I Bjolderup var Folk i den Grad udsugede (ausgemergelt), at det skortede paa Levnedsmidler. Varnss Præsten skriver, at den svenske Hær indtraf i December 1643 og forlod Egnen til Mikkelsdag 1045. Man fik Til til at lare linanden at kende.

Sammenlignet med Kejserkrigen paa denıe Lgn var der 
denne Gang mere Skaansel, hvilket aabenbart stod i Sammenhæng med de anvendte Krigsmetoder.

I Bov skriver man 1657. Sognepræsten døde Langfredag dette Aar, og IPræstegaarden stod derefter tom i to Aar. Den nye Præst kaldedes 1659 og kom fra Felten. Han havde hørt Trompeterne saa mangen Gang. Sognefolkene opholdt sig haade her og der, mest dog i Flensborg eller Kollund. Næsten hver Uge var der døde, fordi den klæbende syge grasserede. Præstens Hus laa i Aske og sin Løn kunde Præsten vente paa indtil videre. Først 1661 begyndte man at bygge og Folkene indfandt sig med Tiden. Prædiken holdtes i Kollund, hvorhen Præsten hentedes med Baad (fra Flensborg,) hver Søndag, somme Tider i stor Fare. Lorens Nissell skankede, skønt han var død for nogle Aar siden, 1000 M., fordi Kirken i Krigen sidstlededn 1659-60 er blevet meget ruineret, Blyet revet af og røvet, saa Gudstjenesten næppe kunde holdes og Sognet for de udstaaede Trængslers Skyld umuligt kunde lade den reparere. En ny Tagstol kunde rejses ved denne Hjælp. En god Mand i Kollund, Hans Tyssen lovede Præsten i Skriftestolen 1666, at han vilde ofre $4 \mathrm{Rd}$. til et nyt Alter. Hele Istandsættelsen af den nedtagne Bygning skal først være fuldført 1698. Klokkehuset blev fornyet 1693 .

I Holbøl Sogn har Krigsfolket huseret slemt. Præsten Mikkel Iversen døde 1663, og Efterfølgeren tiltraadte i bare Elendighed og fik efter megen Tryglen endeligt overladt en ode Gaard 1671. Men værst saa det ud i Kirken. Den 24. Januar 1662 faldt nemlig den øverste Del ned og sønderslog de fleste 5jælker. Da Præsten i sin private Regnskabsbog skriver om disse Tildragelser, angiver han som Grund til Sammenbrudet: 1, har Kirkeværgerne forladt deres Embede: 2, har samtlige Sognefolk foragtet Hr. Mikkels Formaning. Ja Nis Hokkerup og hans Søn har paa 3. Juledag 1661 efter Prædiken fulgt ham hjem med Stok og Sten. De vilde Præsten tillivs, hvilket Asmus Riggelsen dog afværgede. Hr. Mikkels Kone lukkede Doren 
i, saa Nis Hokkerup ikke kunde komme læengere. Saadan gik det altsaa til, at Holbøl Kirke styrtede sammen. Endnu længe efter de Dage vilde der ikke ligge Sten paa Sten. Den vestre Fille byggedes 1673 men faldt ved samme Aar, da Murværket paa Grund af Regn ikke kunde blive tørt. Aar 1693 mindes Præsten, hvad der staar hos Profeten Haggai: "Herren vakte Aanden hos Serubabel .... og de kom og gjorde Arbejdet paa den Herre Zebaoths deres Guds Hus« og gør dertil denne indholdsrige Bemærkning: "Her svor Nis Jepsen i Hokkerup, at Kirken skulde bygges indvendigt, og hele Menigheden var villig dertil. Gud gøre Gengæld mod enhver«. Hvad der skulde genoprettes var sikkert endnu Følgerne af Nedstyrtningen 1662. Men nu svor altsaa Nis Jepsen og saa blev der bygget. Dog stod endnu Vestmuren og raabte om Hjælp. Forst 1703 blev den sig selv igen.

Beboerne i Asbøl havde intet at betale med 1658 og 1659, da de led under Indkvartering og Udplyndring og desuden var spredte rundt omkring. Kirken var opbrudt, plyndret og ilde tilredt. De bortflygtede begyndte at indfinde sig igen 1660, men i Kirkens Kasse faldt der kun 2 M. 2 Skill., som Murmanden fik. Han stoppede vel et Par Huller. Men Vinduerne - for at raade Iod paa dell, bare det allernodvendigste, maatte man laane 20 M. i Dybbol (1661). Endnu 1683 var Klokkehuset helt ruineret, saa det maatte oprejses af nyt. Hans hajgrev. Eksell. lovede $1692 \mathrm{Hj}$ Hp til det usle Tag, men der blev ikke noget af, og imens faldt Loftet ned i den vestre Ende.

I Kværs fulgte 16660 Lungepest blandt Kvæget - Datidens Bonder har ogsaa haft noget at trækkes med -.- hvorved Præsen mistede 5 af $\sin 7$ Køer. Ladegaard var ode. I Hjordkær døde Præsten af Pest 1659. I Uge, hvor bitre Erfaringer endnu laa friske i Sindet, købte man Beskærmelsesbrev for Kirke og Kirkehuse. Alligevel blev Alteret revet ned og Kærterue søndersloges, mens Vinduerne splintredes. Bygningen trængte gennem mange Aar til Medlidenhed og Hjælp. Lutke Larsen i Flensborg skænkede 10 Tonder Kalk, Provsten 20 M., 
Præsten 10 M. og andre Godtfolk i samme Forhold (1694). Men nıed lidt opspilede Øjne ser vi paa de følgende Linjer fra 1691:

Drukket med Smeden for $4^{1 / 2}$ Skill.

Ved Risten drak de 2 Kirkeværger for 3 Sk.

Ved Udmajning af Kirken de samme for 6 Sk.

Ved Indkassering af Lyspenge drukket for $12 \mathrm{Sk}$.

Endnu drak Kirkeværgerne ved Præstegaardens Tækning for 3 Sk., dernæst hos Peder for 13 Sk. og med Niels Mors for 10 Sk. Tilslut sad de sammen med de 12Mænd og lignede Kirkeskatten, mens de slukkede Tørsten for 2 M. 13 Sk. Ogsaa Tobak spenderede Sognet paa dem. Humøret var nok godt. Brændevin og Sorger kan ikke forliges, det vidste man i det 17. Aarhiundrede.

Paa sammme Tid gik den sidste kostbare Pryd paa Felsted Kirke al Kødets Gang: Kobberet paa det stolte Spir. Kirkeværgerne rejse til Flensborg med Resterne; men da det var lappet og medtaget vilde ingen købe det. Endeligt fik de det dog solgt for $163 \mathrm{M}$. Felsted nøjedes saa med Bly. Omkring 1709 laa der endnu mange øde Gaarde i Sognet.

Ensted, Kliplev og Varnæs havde Besøg af Rytterne og saa dem forsvinde i August 1660. Hertug Christian Albrecht gav 1(j70 Lov til at Omkostningerne ved Reparation af de helt brostfældige Kirker i Hjordkær og Logum maatte fordeles paa Sognene. I Østerlogum Sogn, hvor Pesten var haard under Kejserkrigen, døde der demne Gang 197 Personer.

Om Hellevad taler Sognets Krønike. Forstandig Tale vil jeg ikke kalde det. Kirken, siges der, synes at vare gdelagt 1659 og Byen plyndret. Sognet kom ikke mere til Kræfter, tværtimod bredte sig efter Krigen Forarmelse og Tiggeri, hvis Spor man kan følge indtil 30-erne i dette Aarhundrede (1830). Denne Forkommenhed har paatrykt Befolkningen et Præg, som først tilkommende Tider turde faa helt udryddet. Ingen intelligente Folk, som kunde fremme aandelig Opgang, indvandrede, for saavidt som en ufrugtbar Jord og et ufrugtbart Folk bod Intelligensen for faa Chancer (Andresen). Saadan bedomte omkring 
1870 en slesvig-holstensk Prest sit Sogn, skønt han samtidig tilstod, at der var gode kirkelige Forhold. Hvad Jordbunden angik, kunde Præsten have nogen Ret, idet der i ganıle Dokumenter siges, at omkring 1700 var de fleste Marker bevoksede med Lyng. $\mathrm{Nu}$ er Lyngen imidlertid forlængst veget for Ploven. Yi tør haabe at der ogsaa er kommet en Grødetid for Intelligensen, selv om tyske Præster engang mistvivlede.

Kunsten blev trods alt ikke forsømt. Den Maler, som kastede de dejlige Arabesker op over Hvælvingen i Holbøl, lod ikke Efterverdenen vide, sit Navu. Det samme gælder om Portrætmaleren i Bov Kirke. Men den, der malede et "firkantet Maleri« paa Alteret 1670 kaldte sig Ayerschettel, hvilket dog er et gammelt Landsbynavn. Heinrich Billedskærer (Ringeling) arbejdede 1610-20 :ammen med Hans Maler i Kliplev. I Ige lod Kirkeværgerne male Opstandelsen og Dommen, Gud til Ere og til god Ihukommelse. Alter Krucifiks, Stole fik ogsaa nye Farver. Niels Pedersen lod Prædikestolen staffere, medelıs Knud Martensen lod Kristi Billede og Knud Jørgensen lod Daaben staffere. Malerpenslen vilde ikke hvile, og de trofaste Kirkeværger tog sig mangen god Taar, mens de gik fra og til. En ikke ringe Opgave fik Johan Naler fra Aabenraa i Hjor lkar Kirke 1655. Efter at der var brugt 6 Tønder Kalk til at slette og hvid at gøre, malede han raggene oven og nede i Kirken. Spor af hans Arbejde kom tilsyne 1888 , det var Arahesker i gul, rød og sort Kulør. Næste Aar stafferede han Pulpituret (Tabulatur), Skrifte- og Degnestol.

Cdsmykningen af Bjolderup Kirke voldte Argrelse og Fortræd. Malerens Navn faar vi ikke at vide. men han sagdes at være en Søsteriøn til Sognepriesten N. Bjørnsen. Arbejdet blev udført 1697. Et stort Maleri dækkede rimeligvis en af Kirkens vagge. Herom siger en gammel Beretning: "Som den davierende Amtmand i Apenrade troede, at dette Maleri var en Satire paa ham, fordi Maleren havie forestillet Djovelen i Helvele son en Ugle og lian just forte en L'gle $i$ sit Vaaben, hragte lian det med megen Møje saa vilt at Maleriet blev overkalket«. 
Ikke længe derefter døde Præsten. En Kommission blev nedsat for at ordne Sagen med Arvingerne, den bestod af Amtmand Günderoth og Provsten i Tønder Samuel Reimarus. Da Amtmianden antagelig ikke havde glemt sin Vrede og Samuel Reimarus ikke var af en blid Natur, kunde man paa Forhaand regne med, at Frugten af deres Granskninger vilde smage af $\mathrm{Pe}$ her. Det gjorde den ogsaa. Vi læser bl. a.: Was zum anderen die Mahlerey oder vielmehr Schmiererey in der Kirche anlangt haben wir befunden, dass sie mit einem Wort nicht allein nichts wert besonderen auch der Kirche ganz skandalös ist, sodass das Kirchengeld wegen dieser Maklerey und dann auch wegen Auszierung der Frau Pastorin und Kön. Reitvoigts Stuhl 375 M. - ganz übel und unverantwortlich angewandt ist. Den kong. Ridefoged var ikke en Ven af de hertugelige, idet hele var spændingen mellem Kongens og Hertugens Folk i Bjolderup Sogn stærk og havde været det længe. Efter Kirkens Ødelæggelse 1630-40 var der en saa stædig Kamp om Stolestaderne, at Konge og Hertug vilde have Sagen afgjort ved 12 Herredsmænd. I dette bitre Modsætningsforhold maa vel ogsaa søges noget af Forklaringen til Billedet i Kirken og alt hvar der fulgte efter. Præsten maa da have været kongeligsindet. Den gyselige Ugle holder sig skjult indtil denne Dag, hvis ikke den spoger i Kirken ved Nattetider.

Saa glider vi ind $i$ det 18. Aarhundrede. Da var de to Kirker i Kliplev og Kværs, som begge laa under Søgaard og en Tid havde fælles Præst, i en bedrøvelig Tilstand. I Kliplev var Blyet fordærvet, Hvælvingerne havde taget Skade, Taarnet vilde falde til den ene Side, de fleste Vinduer duede ikke, Murene havde slemme Revner og Gulvet var ujæevnt. Indentil spærrede den grevelige Stol og Gitteret (das Gegitter, sammenlign Tønder og Møgeltønder) saaledes at de som sad ovenfor ikke kunde høre Prædikenen og de som sad nede i Kirken ikke kunde se Præsten. Grevens Stol skal skrues i Vejret. Gitteret tilligemed det paa Sydsiden i Koret ambragte Hængeloft (Hangeboden) skal fjernes, især da Kirken har faaet et Orgel, hvor Skoledrengene 
cg Degnen kan staa (de stod altsaa før paa Hængeloftet). Blyet kom først fra Flensborg; men efter at Skibene var komme hjem fra England, hentedes det i Aabenraa. Der brugtes bl. a. 500 Tagsten til Benhuset. Senere meldes om en Hovedrestavrering 1754, hvorved man skal have taget Nikolajkirken i Flensborg som Monster, idet man udstafferede Hvælvingerne paa lignende Maade og dannede Alteret (der dog først byggedes 1775) i Stil med det derværende. I Kværs havde man 1705 meget store Udgifter fordi Kirken stod i Fare for at falde sammen over den forsamlede Menighed. Hele Tagstolen var raadnet.

Om Asbøl hedder det kort og godt, at Hertug Frederik lod Kirken af ny opbygge 1768. Den maa have trængt til det. Da Søren Abildgaard saa paa Holbøl Kirke 1775 kaldte han den forfalden og ringe. I Rinkenæs styrtede Korhvælvingen ned 1799, Korbuen gik ved denne Lejlighed tabt. Til Varnæs Kirke kollekteredes 1764 i alle Provstier. Fra Münsterdorf i Holsten kom der 80 M., Rise fik allerede 1744 Hjælp ad samme Vej. Uge Kirke solgte sit Bly 1726 og sad i Fattigdom. Arnolt Barnsen i Flensborg skænkede nogle Tønder Kalk 1738, at den kunde hvidtes. Prosten sidder og filosoferer over, hvorledes vore I'orfædre har kumnet opføre og saa kostbart udsmykke de store or massive Kirkebygninger, som Efterkommerne næppe er istand til at holde vedlige, hvilket de mange Kollekter beviser. Han mener, det var Skriftestolen og Skærsilden, som gjorde de store Gerninger. Man maatte nu om Dage, hvis ikke det var en Selvmodsigelse, ønske sig en luthersk Skærsild. Han har set lette Ønske fremsat af den i sin Tid berømte Professor og Præst Schupp i Hamborg (som dog kunde være satirisk). Om Alteret gor Præsten den Bemærkning, at det som allevegne er af raa Marksten udmuret med Kalk og at dette af Pavedømmet frembragte Gammel-Testamentleri nok har sin Forklaring 2. Mos. 20, 25. Det sidste Fingerpeg er ikke ilde. Her staar nemlig: "Dersom du vil gøre mig et Alter af Sten, da skal du ikke bygge det af huggen Sten; thi lader du dit Huggejern komme derover, da vanhelliger du det." Saadanne Altre findes endnu f. Eks. i 
Egvad og Bedsted, ogsaa i Østerløgum sidder der Natursten. Mange Steder har man jævnet disse gamle Sten eller beklædt rem.

O'm Hjordkær indberetter Generalsuperintendenten 1751, at Kirken er i saa slet Tilstand, at dens Forfald snart kan befrygtes. Den kan ved Beboernes Fattigdom kun hjælpes ved en Kollekt. Ogsaa Egvad maatte gaa Tiggergang 1780. Det gavmilde Münsterdorf Provsti sendte $69 \mathrm{M}$. Klokkken i Hellevad kaldes, genfødt af Asken i 1738, hvilketl kunde tyde paa at dette A ar har været skæbnesvangert for Kirken eller Taaruet, maaske ved Lynnedslag.

I de udførlige Beskrivelser fra Begyndelsen af Aarhundredet er Kirkernes Tag det mest paafaldende. Det er et Efterkrigsbillede, som mange Steder blev bevaret indtil vore Dage. 'Kobberet forsvinder, Blyet tildels. Ikke blot har hver Bygningsdel sit eget Tag, men halve og hele Sider paa Skibet er med Pander ved Siden af Bly, Taarnet i Rise havde øverst og nederst Bly, i Midten Spaan. Et broget Billede, som klart gav tilkende, at Befolkningens Velstand var ødelagt for et Hundrede Aar, at Evnen til at afhjælpe de store Brøst var brudt. Hvordan det stod til med Viljen kan vanskeligt siges. Men det er givet, at vore Landsbykirker efter det 17. Aarhundredes Oplevelser iklse mere var de samme. De gamle Slægter som laa i deres Grave vilde have set paa dette Billede med Sorg. Med en Slags vemodig Nøjsomhed og Ligegladhed siges der om Kirken i Løjt: Sie ist inwendig gewölbt und in ziemlichem Stande, die gestüllt aber sind nach Hausmanns Art. Pragten var borte, men for Husmænd var det godt nok.

Man havde Lyst til at male. Joachim Schultz malede Kliplev Kirke 1704. Johan Lorentsen Krøger, Kobbersmed i Haderslev, lod fremstille den yderste Dom i Bov Kirke 1740. Sognepræsten lod sig selv male og skænkede en Krystalkrone samt $100 \mathrm{M}$. til Renholdelse af begge Dele. Han kendte Støvets Magt i denne Støvets Verden. Den Mand, som malede Stole, Døre og Loft i Kværs 1750, kaldes Tischler Nis Hansen in Quars. Derimod var 
det Maleren Nicolaj Nissen i Varnæs, som malede i Holbøl 1797. Samme Sted havde Købmand Klaus Richelsen i Flensborg ladet sætte et stort Contrefait 1729, som forestillede den yderste Dom, et meget yndet Emne i de Tider. Hr. Knud Andersen i Fensborg lod hele Uge Kirke renovere 1762 ved Maleren Thorkild Petersen fra Løgum. I Varnæs, Løjt, Bjolderup og mange andre Steder malede den flinke Jes Jessen, engang C. V.. Eckersbergs Læremester. De smaa Blomster paa sort Grund i Stolegavlene er yndefulde og skulde gerne bevares, men alt $i$ alt er ogsaa hans Arbejder et Udtryk for det 18. Aarhundredes Ikke-Kunnen.

Hvidtekosten $\mathrm{i}$ det 18. og Udrømningen i det 19. Aarhundrede har ogsaa sat Spor i disse Kirker. Kun et Eksempel. Træd ind ad Hoveddøren i Østerløgum Kirke. Du standser et Øjeblik paa Tærskelen, mens dit Øje søger frem gennem det store Rum. Ved sin Højde og Længde er dette Rum ikke uden Virkning. Men hvor tomt! Helt der langt borte i Øst ser du gemnem den lave Korbue et Parti af en Altertavle, der endnu nogenlunde er sig selv. Gaa nærmere, at du kan se det hele. Du begynder at smile ad de fjollede smaa Heste, men de er muntre, ikke sandt? Vi hører dem vrinske. Vi hører ogsaa Menneskestimlen raabe og støje. Du smiler igen: alle Munde er jo lukkede. Ja vel, saa er der et stille Øjeblik. Der er noget, som har faaet Stimlen til at tie. Et Raab deroppe fra, en fjern hendøende Klage, et Suk som fra en Verdens Undergang. "Jeg tørster". Se, her kommer allerede han med den lange Ysopstang og Svampen. Ogsaa han er tilhest, har endda ondt ved at naa helt op til de torstende Læber. Skøn er han, denne Rytter. Han giver den sidste Lædskedrik til en døende. Og det er Addike. Men hvorfor holder han der endnu, hvorfor sænker han ikke sin Lanse igen? Er det ikke nok, skal der drikkes Eddike i hundrede Aar? Du hører ikke paa mig, du staar allerede og betragter Historiens sidste Del, det nederste Passionsstykke i Fløjen tilhøjre. Det er Gravlægningen. Se, denne Kvinde, der kaster sig paa Jorden ved Ligets Side, saa voldsomt som om hun skulde fare ud af IRammen ned imod os. Han har glemt, at Silkekjolen let brister 
under saa spændende en Bevagelse, at Fløjel er for sart til at ligge i Støvet. Nu slaar hun sin højre Arm om de blege Ben og Munden nærmer sig for at kysse det aabne Saar i Foden. Underligt at staa her lige foran som Tilskuere. Vi bliver smaa, du og jeg. Det fylder mere end vore smaa Kar kan rumme. Og dog var der meget mere at se - engang. I denne Hvælving, næsten en Kuppel, var der Ranker og Figurer i fulde Farver. Dernede paa de svære Mure i Skibet bevægede sig en broget Flok af bibelske Skikkelser lige saa levende som Menigheden, der sad i disse Bænke. Ved Kormuren stod Alteret med prægtigt forgyldte Figurer. Disse Stolestader eller deres Forgængere med smaa Gavle og Døre var holdte i Grønt som Bøgeskoven ved I'insetid eller i Gult som Liljen ved Paasketid eller i Lila som Inghyacinten i Maj. Over det hele løb de mørkebrune Bjælker Side om Side, som troligt og trygt afslutter Rummet uden at c tynge. Højt oppe sad de klassiske smaa V'induer, hvoraf et endnu ses $i$ en Krog i Koret, sømmet til et Brædt. Saadan var det engang. Hjemligt, kulturfyldt, fortidsfortroligt, fortællende. Det maa have været tørre og idetomme Slægter, som fuldbyrdede denne General-Annullering af Liv og Skonhed. Det vil vare længe, inden Østerlogum Kirke og hendes lange ligklædte Søstre faar det igen som frarøvedes dem for et Par Hundrede Aar siden.

Lad os gaa. Her var stille og stemningsfuldt endnu trods Tomheden. Uden for Kirkegaardsporten lugter Vejen af Benzin.

Et Billede fra Restaurationstiden har vi i Ensted. Her var en fuldstændig Fornyelse nødvendig 1840. Omkostningerne skulde dækkes ved Salg af Blyet og blev det. Langsomt skred Blyet ned fra sit aarhundredgamle Leje, først 20.000 Pund, saa 1200, saa 1100 og tilsidst 9.000 . Kirken stod derefter med røde Tagpander i det Ydre og hvidt Gibsloft i det Indre. Fortiden kendte den ikke mere.

Paa samme Maade restaurerede man i Holbøl og Hellevad ved at sælge det gamle Bly, i Hellevad 40.000 Pund. I Bjolderup derimod gjorde man et uventet Fund 1845. I et Hjørne over 
Taarnhvælvingen opdagede Kirkeværgen en stor Klump Bly, som med meget Besvær hævedes og viste sig at veje 1500 Pund. Blyet maa have ligget der siden Branden 1628. Det blev ikke solgt, men støbt til Blyplader igen, som det engang liavde været.

Tiden har været haard ved Rise Kirke. Det maa vi sige. Taarnet brændte af Lynild 1627, hele Kirken nedbrændte 1893. Det gamle Alter fra Middelalderen med et Billede af Jes Jessen vandrede til et Museum i Kiel. Prædikestolen gik samme Vej, men Skjulet over den blev paa sin Plads indtil det hele brændte. Pastor Wulff længtes efter skønnere Sang i sin Kirke og skænkede den et Orgel. Det havde engang musiceret i selve Domkirken i Slesvig, derefter i den lige saa ærværdige Klosterkirke i Løgum og kunde ikke tjene til evige Tider i Rise. Det var ellers "von reizendem Aufbau«. Da det forfaldt, fik man et fra Helligaandskirken i Kiel. Det brændte og tav for stedse. Saaledes har hver Ting sin Skæbne. Ellers siger Søren Abildgaard om Rise Kirke, at han fandt den nylig pyntet og malet.

Af Malere træffer vi foruden den allerede nævnte Jes Jessen den russiske Maler Rosenborg, som portrætterede Præsten Th. Hoyer Jensen i Bov, Maler Kruhl, der arbejdede i Bedsted (1802), Maler Nielsen, som smykkede Uge Kirke (1855), Maler Kjer, som arbejdede i Hjordkær (1831).

\section{Bygningens enkelte Dele.}

De mange Klokkehuse af Træ er der talt om ovenfor. Hvor gamle de er, er ikke let at sige. Ensted fik sit smukke Klokketaarn 1826, det yngste af dem alle. Men det var en Afløser. Hegnskabet kender allerede 1750 en Bygning med 2 Klokker. Asbøl taler 1708 om Erbauung des grossen Hauses, men 100 Aar før repareredes der paa et Klokkehus. I Kværs er der Tale on et nyt Klokkehus 1720 (Errichtung des Glockenhauses) og der er 1816 en Udgift an den Baumeister des Glockehauses; men saadanne Udgifter var der ogsaa i 1705 . Uge fik et Klokketaarn 1685 , Hjordkær et 1633 , Holbøl et 1649, Varnæs et, som det synes, 
længe før. I Hjordkær var man ikke tilfreds med denne Fortrolighed. Det lykkedes at faa bygget et rigtigt lille Taarn paa Kirken 1747, ved hvilken Lejlighed Trætaarnet rimeligvis forsvandt. Men 1793 fik Herligheden en Revne og maatte rives ned. Af Tømmeret byggedes atter et Klokkehus. $\Lambda$ t bygge et højt Spir igen var for svimlende en Tanke for Hjordkær Sogn indtil denne Dag. Den Mand, som stod i Spidsen for Taarnbyggeriet 1747, laa under Kirkegulvet og ligger der vel endnu.

Storprovstens gamle Kirke i Felsted havde et Spir (Rytterspir), der ogsaa kaldtes et Taarn. Det forsvandt 1762 , og et Klokkehus rejstes i Stedet 1769. Da var den sidste Storprovst død for længe siden. Det segnende Spir var Slutningen paa en gammel Drøm. Men i Folkets Sind levede Drømmen videre en Stund. Kirkeværgerne $\mathrm{cg}$ en Del Bønder lagde Planer om et nyt Taarn 1776. De lovede at bidrage hvad de kunde. Asmus Thaysen vilde give en Eg til en Mittler-Bau-Seule i Taarnet (Kongebjalken). Til de store Godsejere i Sognet skrev man bl. a., at et Taarn i mange Aar har været længselsfuldt ønsket af Menigheden; men for Uformuenhedens Skyld har Ønsket ikke kunnet virkeliggøres. Men Sagen veg tilbage til Drømmenes Land. Præsten var vel den sidste, som slap Taarntanken. Da han byggede den smukke Præstegaard 1787, lod han skære et stolt Spir i Dørens to Fyldinger.

Saa er der Kliplev tilbage. Her knejser Spiret endnu paa det høje Tag. Det staar lidt uregelmæssigt i sine Linjer og Sammenføjninger, som om det havde været ude for megen Modgang, hvad det selvfølgelig ogsaa har. Men se saa det brede, fast tomrede, tilsyneladende urokkelige Taarn af Eg derhelme paa Nordsiden af Kirkegaarden. Grønsvær rundtom med et Par forladte og glemte Grave, hvis Beboere dog havde et Navn engang. Den gamle brede Dør aabner sig, og Beskueren standser uvilkaarligt ved Tærskelen, inden han gaar længere ind $\mathrm{i}$ Fummet. Et Spil af slumrende rolige Kræfter, viede, som det synes, til Evigheden, lukker sig langsomt op for Øjet, som om de vaagnede i dette Øjeblik. I Midten den smukt forarbejdede 
kæmpemæssige Stolpe, som de Gamle kaldte Kongebjælken. Det er en Eg fra Sundeveds Urskove, som er flyttet herind, og den staar, som om den gror videre i Jorden. I Korsform skyder den sine svære Grene ud til Siderne, og dens Børn kravler i Form af skraat indad hældende Andreaskors opad paa de fire Sider. Denne Eg plantede sig selv engang, længe førend en hertugelig Hegereiter red gennem sit Rige. Maaske den har været rodfast i 500 Aar og luftet sine Grene i Vinde fra Alssund for 1000 Aar siden. Mange Menneskeslægter er baarne til Graven siden den var ung, men dens Styrke bærer endnu Taarnet. Er der nogen, som ser det? Mange gaar forbi. Ungdomsskarer sværmer gennem Landet, de skal se Dybbøl og Rudbøl og Flensborg Fjord. Men ser de den gamle Eg i Kliplev? Kommer der - det kunde jo tænkes - et halvt Dusin skandinaviske 'Tomrersvende, da luk dem ind i Taarnet, og mener de at kunne klare det derinde med nogle Vittigheder af sidste Aargang, saa drej Noglen om og luk dem ikke ud, før de kan gøre Rede for hvert Baand, hver Sammenføjning, Grundrids, Omrids og Rejsning, og indrømmer, at der var Svende for et halvt Aartusinde siden, som kunde skære et Stykke Egetømmer tilrette. Men for ikke at tage Munden for fuld paa de gamles Vegne skal jeg vedgaa, at ogsaa dette Tømmerværk, der synes aldrig at kunne vige en Tomme, engang truede med at gaa fra hinanden, og maatte hjælpes tilrette igen. Det var under Klokkeringningen 1746 i Anledning af Hs. Maj. Kong Kristian VI.s Død. Her som allevegne var det Klokkerne, som bragte saa mangt et Taarn med tykke Mure til at give sig i Knæerne. Naar to Klokker sattes i Bevægelse, svingede $500-1000 \mathrm{~kg}$ (et almindeligt Vognmandslæs) frem og tilbage i Timevis. Her skulde Modstand til. Og dog staar den gamle Eg aabenbart just som den stod, da den første Mester og hans Svende gik fra den. Lillebæltsbroen er et Storværk, en Pragt, en kraftig Bindestreg mellem Jylland og Fyn. Men lad os tale om dens Sammenføjninger om 500 Aar.

Kan hænde, at Kliplev Klokketaarn da staar uforandret kan hænde, at disse Blade da ligger ormstukne i et Arkiv - 
kan hænde, at en Historiker da tager dem frem og gor Sammenligninger. Men nok om det. - Luk saa op for de seks nordiske Tømrersvende og lad dem trille videre.

Selve Kirketaarnene formaar vi ikke at datere. Men i Løjt nævner man Aar 1480 og viser det Sted, hvor Tommeret blev taget. Hellevad Kirketaarn bærer i sin Hvælving Tallet 15 Anno 28. Det er ikke urimeligt, at Taarnet stammer fra dette Aar, skønt der samme Sted læses, at 1521 kom Kasø fra Hellevad. 'Taarnet i Østerløgum styrtede ned 1718 og rejstes igen. Spiret i Bjolderup ramtes af Lynet 1856. I Rise bar Taarnet endnu 1819 et Kobbertag, men Kobberet blæste ned, da det var daarligt lagt paa.

Benhuse omtales i Kliplev, Aabenraa og Asbøl. Vaabenhuset i Varnæs kaldtes ogsaa Lighus. At Vaabenhusene er benyttede til Skolestue meldes der ikke noget om fra dette Provsti.

Et Halsjern hang uden for Kirken, som oftest vel ved Klokkehuset, og tjente som Gabestok. Hjordkær købte Jern til dette Brug 1637. Kliplev gemmer endnu et Halsjern med Kæde, som i sin Tid var fastgjort ved Kirkegaardsporten. Det ærværdige Klokketaarn skulde ikke have den Skam. Ved det ældgamle Klokketaarn i Varnæs hænger endnu to Kæder, den ene med et Halsjern. Gabestokken fra Ensted er udstillet i Aabenraa Museum.

Mere Plads maatte skaffes tilveje alt som Folket tog til i Tal. Asbøl Kirke havde daarligt Raad, men gik dog i Gang dermed 1690. Der byggedes ein Kirchenchor oder Boden, ogsaa kaldet en Hangelbowen (Hængeloft, fastgjort ved Bjælkerne). I Bov byggede man en Sektor 1704, om hvilken Sognepræsten 200 Aar senere siger, at nu, da Sjæleantallet vist er over dobbelt saa stort, vilde dette Loft være fuldstændig overflødigt. En god Ven lod et Loft bygge i Kværs 1718. Rinkenæs havde 1723 baade et gammelt og et nyt Ambonium. De fleste andre Kirker fulgte efter. 


\section{Genstande til Brug ved Gudsdyrkelsen.}

Naar vi tager Historien med ind i Kliplev Kirke, kan det høje Kor sætte vore Tanker i Bevægelse en Stund. Præsten $i$ Holbøl, Samuel Nissen, har i sin Tid optegnet et Par Sætninger, som vi er ham taknemlig for. Hans Interesse gik ud over hans eget Sogns Grænser, og om Kirken i Kliplev mener han, at den uden Tvivl maa være indviet til den hellige Jomfru Maria, fordi hendes hele Levnedsløb fra Undfangelsen til Himmelfarten er at se udhugget i Alteret ex jacobi protevaggelio. Ellers har den til sin Patron Frelseren selv, S. Salvator, paa Dansk: St. Hjælper kaldet, hvis Billede skal have udrettet store Mirakler. Af den Grund er der stadig anstillet store Valfarter derhen o. s. v. En Præst i Adelby fandt $i$ en gammel Bog et Raad mod Træernes Ufrugtbarhed; men naar dette Raad ikke vilde hjælpe, so helffet Sankt Hjelper in Cliplef. Saadan fortæller Hr. Samuel. Det var omkring 1710. Da stod altsaa St. Hjælper ikke mere (ellers vilde Præsten have fortalt det) og har rimeligvis ikke været at se $\mathrm{i}$ hans Dage. Indtil 1628, siges der andetsteds, var den lemlæstede Krop af det undergarende Billede endnu i Kirken; men da kunde St. Hjælper aabenbart ikke mere hjælpe sig selv. Ovre i Ahlefeldernes Gravkapel ligger en mægtig Sten over Hr. Gregorius, som faldt i Dithmarsken 1559. Han havde et Valgsprog, som udtaler Tillid til den guddommelige Hjælper. Er det ikke et Genskær af den gamle Glans fra Valfartskapellet i det modsatte Hjørne af Kirken? Her stod rimeligvis det rigt forgyldte Billede af den Korsfæstede med Kongekronen paa sit Hoved. Her var det, Miraklerne skete. Men St. Hjælper var altsaa ikke mere. Heller ikke det Alter, som Præsten endnu saa, er mere. Men lad os i Tankerne staa ved hans Side nogle Øjeblikke og se med hans opmærksomme Øjne. Vi ser udskaaret i Træ nogle Scener af et Evangelium, som kaldes Jakobs Protevangelium, d. e. en Fortælling om Tildragelser, som ligger forud for de egentlige Evangelier, altsaa Legendestof. Dette Evangelium skildrer i 25 Kapitler Jomfru Marias Liv fra Bebudelsen af hendes Fødsel indtil Barnemordet i Betlehem. Marias 
Forældre var Joakim og Anna, som bønfaldt Herren om Livifrugt, idet Anna lovede, at Barnet livsvarigt skulde tjene ham. Tre Aar gammel overgaves hun da til Tempeltjenesten og med 12 Aar blev den rene Jomfru trolovet med den gamle Enkemand Josef. En Dag, mens hun broderede paa Templets Forhæng, kom Englens Budskab til hende om det forestaaende Moderskab, som hendes Legeme intet vidste om og som Sjælen tænkte paa med en hellig Skælven. Maria, den ubesmittede Jomfru, den eneste rene Kvinde, uplettet før og efter Frelserens Fødsel det er Evangeliets inderste Hjerteslag. Saadan er hun blevet den katolske Kirkes kæreste og skønneste Blomst, det jordiskhimmelske i underfuld Forening og straalende Yude. Himmelsdronningen. Som en tysk Teolog har udtrykt det: das Ideal der in Gott verklärten Weiblichkeit. Det er Billeder af dette stille og gudfyldte Kvindeliv, Holbølpræsten saa og blev betaget af $i$ Ḱljplev Kirke. Men Præsteme i Kliplev synes at have haft andre Øjne at se med. De fandt ikke Behag i denne Altertavle. Aar 1775 rejstes en ny, som skulde være lidt i Slægt med den i sit. Nikolajkirken i Flensborg. Et mægtigt Vark er den med et Par store fritstaaende Figurer ved Siden, i Midten Opstandelsen malet af Jens Martin Lund i Flensborg. Regnskabet for 1775 opforer blandt Udgifterne: An den Möller Peter Christian Hansen auf Dalsgaard bei Verfertigung des neuen Altars $66 \mathrm{Rd}$. An denselben für Verfertigung des neuen Altars $600 \mathrm{Rd}$. Hr. I.undt aus Flensburg für Malerei $67 \mathrm{Rd}$. Denne Billedskærer kendes ellers ikke, saa vidt jeg ved. Mærkeligt nok blev Prædikestolen i Kværs sat istand af en anden Mand paa Dallsgaard, Hans Peter Carstensen (1804). Dalsgaard ligger i Rinkenæs Sogn. Den rene Jomfru forsvandt fra Kliplev. Ruinerne af hendes Alter solgtes 1789. St. Hjælper og hans Moder, som i Hundreder af Aar havde været æret og tilbedt under de høje Hvælvinger, den ene i Højkoret den anden i sit Kapel, var nu kun Stumper af svundne Herligheder, værdilose Rester af en Kultus og et Aandsliv, som ingen mere forstod. Ovre paa Væggen lige uden for Døren til St. Hjælpers Tempel staar en Figur, 
som hvẹ halve Time slaar paa en lille klokke. Han slaar og slaar. Og Tiden gaar. Slægter kommer og Slægter forsvinder. Hvad der var helligt for den ene, kaster den anden i Brokkassen. En gammel Præst sidder og skriver det op, saa dør ogsaa han.

Mange Altertavler fra Middelalderen er endnu bevarede i dette Provsti. Et Par har i den seneste Tid faaet Lov til at. iføre sig deres oprindelige Farvepragt, nemlig i Løjt og Egvad. Hver af de to Tavler virker paa sin Maade og i sit Rum; men Pragten er størst i Løjt. Da jeg traadte ind i denne Kirke for at tage det hele Rum i Øjesyn, begyndte jeg straks ved Døren og gjorde, som jeg plejer, mine Optegnelser, idet jeg roligt og langsomt skred frem fra Orgel til Prædikestol, fra Skib til Kor. Men da jeg stod foran Alteret, puttede jeg uvilkaarligt Papiret i Lommen. Skrev ikke mere, men bare saa. Fra Enkelthederne til Helheden og atter fra Helheden til Enkelthederne. Saadan altsaa stod Værket færdigt for 400 Aar siden, saadan gennemstraalede dets Guld den hele Kirke endnu længe efter at Evangeliets klare Dag havde sendt sine Straaler ind ad dens Vinduer. Saadan fremstod det paany i en Tid, da Kirke og Middelalder synes at være Beter i Dagens larmende Spil. Det har ikke kunnet dø.

Ellers har de gamle Tavler været udsatte for adskilligt i Tidens Løb. I Bedsted er de 40 Figurer blevne hvidmalede, vel nok i det 19. Aarhundrede. Engang var de spillevende og mylrede frem over Golgattas Bakke, nu er de gustne Lig, blege Gengangere. Et Rammeværk med Udskæring og Farver er føjet til, saa at hele Tavlen er blevet saa stor at den kun delvist kan ses gennem Korbuen. Ogsaa Tavlen i Hellevad er blevet forstørret med 14-15 smaa Figurer, som man har fundet andetsteds i Kirken, maaske over Korbuen.

Rigdom og Fylde var der engang i Holbøl Kirke. Tre Altre betjentes af tre Munke. Men hvem Kirken var indviet til, har der været forskellige Meninger om. "Vor Kirke», siger den før nævnte Samuel Nissen, "var uden Tvivl en Mariekirke, da hen- 
des Billede ses flere Steder. Men Patron var Ridder Georg, som ses tilhest. I Alteret-ligger en stor Helligdom, som endnu ses i et Stykke Bly, uden Tvivl fortættet Mælk af Jomfru Maria. Midt i Alteret er der en stor flad jævn Sten, deri et firkantet Hul hugget, hvori omtalte Mælk ligger i en Blybosse (forhen uden Tvivl af Sølv eller Guld) og oven over en Serpentinsten. Da jeg fandt sammme vilde jeg grave videre efter og se om der var flere Reliquier i Alteret. Men da jeg vilde tage den store flade Sten ud, kom der mig en saadan Gysen paa, at jeg maatte lade alt blive in statu quo. St. Johannes var ogsaa en stor Helgen i Holbøl. Dengang sal. Hr. Povl Sommer (1664-1702) tiltraadte sit Embede, plejede Hans Tøjsen en Søndag Morgen tidligt saa snart Kirken aabnedes, at gaa ind og falde ned for samme (Johannes) og tilbede. Da Hr. Sommer overraskede ham derved lod han Billedet og andet i Kirkehuset flytte, og da ommeldte Hans Tøjsen ikke desmindre holdt Tilbedelse ogsaa der, blev de (altsaa flere?) endog kastede ud paa Kirkegaarden, $h_{1}$ vorover han besværede sig, foregivende at man ikke skulde omgaas saa ilde med de gode Helgener. Ellers har ogsaa mange i Menigheden holdt store Stykker paa den store Kristoffer, som var malet paa Nordmuren«. Altertavlen har nu et Billede fra det 18. Aarhundrede, som visselig ikke skal faa Folk til at knæle i Henrykkelse. Paa Alterbordet stod engang en Kalk, som var frelst ud af Vandfloden paa Nordstrand (so noch aus dem strande gerettet) overladt Menigheden af sal. Hr. Sandhagen, som derfor fik $4 \mathrm{Rd}$. Men hvad Vandet havde sparet blev et Bytte for en menneskelig Kæltring. Der staar at læse fra 1693: I dette Aar blev vor Kalk og Disk stjaalet af Klavs Skolemester eller Svarrer. Han blev hængt den 10. Sept. 1694 og Karen Knap hudstrøget og landsforvist, fordi hun havde hælet. Retsomkostningerne gik op paa $80 \mathrm{Rd}$. Men saa var man ogsaa sikker paa at den Tyv kom ikke igen. En Del af Solvet stod længe i Retten paa Graasten "verarretiert" til Sikkerhed for disse Penge. Man fik det først 1703. Noget Sølv blev lagt til og saa fik Kirken en ny Kalk. Nogle Aar senere overraskedes Præsten en Dag ved 
paa Alteret at finde en Pakke med 16 hwffnagels (Hesteskosøm) af Horn. Han blev saa medtaget af dette Syn, at han med det samme kundgjorde det fra Prædikestolen. Den skyldige kom derefter frem og bad om Forladelse; der var handlet i Overtro (1714).

Lige som i Kliplev og Holbøl var den hellige Jomfru kraftigt tilbedt i Felsted. Hovedindholdet af den endnu staaende Altertavle er efter R. Haupt: eine Verherrlichung der Maria. Den restaar i Hovedstykket af to Rakker Figurer under Baldakiner I deu overste er Kristus med Verdenskuglen i sin Haand og Krone paa Hovedet, ved hans Side Jomfru Maria, ligeledes med Krone. Det er St. Hjælper og hans Moder om igen som i Kliplev, her fremstillede $i$ et og samme Billede. Gennem hele vort Tidsrum gaar der en Stræben efter at udvide Middelalderens enkle firkantede Fløjalter (Skabe). Havde man ikke Raad til at lade nye Udskæringer sætte paa, tog man hvad man fandt ellers i Kirken. I Felsted var der aabenbart nok at tage af. Danske Atlas mindes endnu mange Helgenbilleder, som tilsidst ganske forfaldt og blev udryddede. Ligeledes var der foruden Højalteret to mindre, som tog for megen Plads og derfor fjernedes "for mange Aar siden". Im Zwiebogen des Chors - hedder det 1763 - stehet ein grosses Krucifix daneben zwei Marienbilder. En Snes Aar senere nævnes det endnu paa sin Plads; men det er aabenbart denne Gruppe som engang stabledes op over Alteret. Et gammelt Alter stod paa Nordsiden ved Indgangen til Koret, hvor det staar endnu, halvt skjult af et Pulpitur. Selve Korbuen blev paa et vist Tidspunkt forhøjet til et rent Uhyre. De, der sad paa Politurerne vilde vel se Præsten, ogsaa naar han stod foran Alteret.

For at blive ved Jomfru Maria skal jeg bemærke, at i Bov hlev hendes Billede brændt, ikke af rasende Billedstormere men fordi Bornene drev Spot dermed. Til Altertavlen lod man male et Nadverbillede efter Datidens Krav af J. Agerschettel med Herredsfogedens Navn og nogle Portrætter (1670). Hundrede Aar efter brændte det hele, fordi man glemte at slukke Lysene. 
Den nye Tavle, til hvis Anskaffelse man fik 600 M. af Brandkassen, var et Vark af Billedhugger Windekiel. Han gav ikke megen Kunst for Pengene.

I Uge maatte man tage til Takke med en gammel Altertavle fra Bylderup. Den findes nu ikke mere; men de Apostelfigurer, som staar i Kirken, stammer vel fra den. Den nye (1694) er nıed meget kraftige Barokformer.

Bjolderup har en Altertavle fra 1639/40. Hjordkær har en fra omtrent samme Tid med Malerier af J. Jessen i Aabenraa. Fnsted rejste ved frivillige Gaver en ny Altertavle 1840 med et Billede i Midterpartiet af Kristus i Getsemane (bag Glas) en Kopi af Eckersberg, Kværs har en Tavle fra samme Aar, malet af Jessen i Flensborg (Midterbilledet af Henningsen).

Paa Alterbordet i Kliplev stod der 1763 eine silberne Giesskanne indvendig overgyldet, en Sølvkalk, forgyllt baade indog udvendigt, 4 gamle ulige Messing-Lysestager. En paafalden(le Rigdom. Asbøl bogførte omkring 1590 (eller før) foruden Messeredet $o$. a.

1 kleine Ketel

1 olde Ketel tho Kole

1 thynuen wynflasche

1 Kopper grape (Kobbergryde)

1 sulveren lepel (Sølvske)

1 Klippingk (Pengestykke?)

2 syden bende 1 grön onde 1 geele (grønt og gult Silkebaand).

Silkebaandet var uden Tvivl et Brudesmykke. Men hvad de mange Kedler og Gryder har været brugt til, formaar jeg ikke at oplyse (Ild, Røgelse?).

Prædikestolene i Løjt og Østerløgum er gamle og mærkelige. Ogsaa Asbøl fik en Prædikestol i det 16. Aarhundrede. I Regnskabet 1591 lases et Memorial von dem Predigtstole: So is to wetende dat nademe de Predigtstol alhie in desser Kerchen gantz veroldet thom dele ock van einander gescheiden gewesen ist (den var forældet og skiltes fra hinanden). So ist ein Pre- 
digtstol van Broacker Kerchen genamen und allhie wedderumme opgesettet, davor tho einer bekenntnisse vorothgegenen 5 Dl. Nis Sniddeker fik $18 \mathrm{Sk}$. for at sætte den op, Peter Maler i Sønderborg $1 \mathrm{Rd}$. for at male den. Vi erfarer paa den Maade, at baade Asbøl og Broager var forsynede med Prædikestol allerede tidligt $i$ det 16 . Aarhundrede, uden at vi faar noget at vide om, hvordan de saa ud. Den Stol, Asbøl modtog fra Broager, vilde vi meget gerne have set; men den er bukket under for Tidens Omskiftelser. Rimeligvis stammede den fra Middelalderen.

Den Prædikestol, der (efter Sigende 1606) rejstes i Rinkenæs, var en Seværdighed i Egnen paa Grund af dens Indskrift. Der stod: Dorothea Mundt mit Navn monne være thenne Prædigstol gaf jeg til Guds Ere. En adelig Kvinde nedværdigede sig til at skrive Dansk!

I Kliplev blev Prædikestolen o. m. a. skaaret af Heinrich Ringeling og malet af Hans Maler fra Flensborz. Over Udskæringerne undrer man sig, naar man tænker paa Mester Henriks Storværk i vor Fruekirke i Flensborg. Han kan næppe selv have lavet Sagerne i Kliplev.

Nis Asmussen Konn. May. Herdesfoget in Wissherde tho Oldemorstoft erffgeseten og hans Hustru lod sætte Prædikestolen i Bov 1626. Denl smukke Stol i Uge er fra 1633 og stod uden Farver indtil 1694, da Nis pettersen diese Cantzel stavieren lassen. Den bærer 3 enkelte Figurer, Tro, Kærlighed, Haab, og staar idag igen uden Farver som i Begyndelsen. Der knytter sig følgende morsomme Fortælling til den: "Prædikestolen laa mellem Kor og Skib saa lavt, at Præsten næsten stod i Højde med Tilhørerne. I Begyndelsen af det 19. Aarhundrede stod en gammel Præst i Sognet. Han var født der paa Stedet og havde ikke kunnet faa et bedre Kald. Man kaldte ham Bødkeren i Uge, fordi han bankede dygtigt paa Stolen. Nu var han gammel og Menigheden kaldte ham Fader. Lige foran Prædikestolen stod Søndag efter Sondag et Lem af Menigheden, gammel af Aar. Naar nu Indledningen var tilende og der opstod en kort Pavse, 
plejede denne at holde sin Daase frem til Præsten paa Stolen med disse Ord: "Far, tag Han nu forst en Prise».

Iblandt de øvrige Prædikestole skal kun nævnes den i Bedsted, fordi den har en Indskrift, som bestaar af gamle kraftige tolinjede Rim paa Dansk.

De ældste Klokker hænger i Asbøl og Bedsted, den før'ste fra 1504, dell anden 1490. I Asbøl var der 1593: ell Klokke i Klokketaarnet, 2 smaa Klokker "hauen dem Chore« og en lille Klokke "op dem Chore«. En af de mange er formentligt omstøbt 1504. Bedstedklokken skal vare støbt i Helligdal og bærer en Indskrift, som trænger til fornyet Tolkning. Ogsaa Hjordkæl' ejer en Klokke, som skal være hjemmestøbt (paa Grønmark). Et Sagn fortæller, at en Rytter kom forbi og kastede noget i Formen, hvoraf Klokken fik sin klare Klang. Men om Kliplev ved vi bestemt, at der foregik en Støbning (Omstobning) paa Stedet i 1636 og 1638. Støberen fik 50 M., hans Svend 6 M., desuden fik han og hans Folk Kost og Bolig i 3 Uger. Der leveredes mange Sager til Støbning af den store og den lille Klokke.

Messeklokker omtales i Asbøl, Bedsted, Bjolderup, Ensted, Holbøl. Da Præsten Ove Johansen i 1508 indsattes i sit Embede i Ensted, rørte han efter den gældende Ritus ved Kirkens Ring, dens Klokker og ved Messeklokkens Strenge. I Egvad hæenger den lille Klokke endnu bag Alteret; men dens Lyd høres ikke mare.

I L'ge levede 17iti en »meget habil Mekanikus« navnlig Bakmanı, som gjorde Briller, alle Slags optiske Sager, Urværker, endog med Klokkespil«. Hall har arbejdet i Omegnen, men hvilke Urværker, han har været Mester for, ved vi nu ikke. I dette Provsti finder jeg kun Efterretning om et eneste fra gammel Tid, nemlig i Kliplev, og det var allerede gammelt, da Mester Bakmann begyndte sin Kunst, Peter Ludiksen, Urmager i Hopdorff, arbejdede paa det 1610 og 1613. Sejermageren Peter Steensen fra Flensborg fortjente en Skilling ved det 16:24. Kapellanen $\mathrm{Hr}$. Niels havle det vigtige Hverv at stille det. Gaa kan det endnu - om ellers det er sanme Vark. 
I Bedsted brugte man "et Jern-Deksel til at hente Ild i at roge med over Ligene" (vistnok et gammelt Røgelseskar). Samme Sted gik Ligklædet af Brug, da man farvede Kisterne sorte (1765). Den oftere omtalte Røgning saavel som de saakaldte Pestilenslys, der sattes paa Kisten endnu langt ned i Tiden, stammede aabenbart fra Pestens Tider.

Ude paa Kirkegaardene var der ikke meget glædeligt at se. Blomster og Mindesmærker paa Gravene kendte man ikke meget til. Men fra Løjt melder Da. Atlas, at der er henved 300 Ligstene, hvis Antal aarligt formerer sig. Dette var sikkert noget aldeles enestaaende i det 18. Aarhundrede.

Snarere var Kirkegaardene endnu langt ned i Tiden uordentlige og forsømte. Det er Provsten i Aabenraa ( $T$. Arnkiel), som skrev, at det mange Steder var kommet saa vidt, at Guds Ager var blevet til en Svineager, til en Hesteager, til en Møgager. "Ak, hvor ofte har man prædiket derimod og advaret Folk baade af gejstlig og verdslig Stand, saa vel som i Hjemmene, i Fællesskab og i Særdeleshed, men alt forgæves! Nitimur in petitum “ (vi stræber efter det forbudte).

\section{Forsvundne Kirker.}

I Genner og (Norre?) Ønlev var der Sognekirker, som forsvandt allerede for vort Tidsrum. Et Kapel ved Aabenraa med et berømt Bilede af St. Anna maa være forsvundet i Kirkespaltningens Dage.

Det Kopel, som var udi Obenraa

det er ren slet, som det monne staa.

De Holste (slesvigske) Bønder kunde det nu mærke. at det var Skoltshed af de Klerke,

Djævelen monne der sin Ondskab virke

og lod sig der af Menneskene dyrke.

Thi bleve de Bønder saare vrede,

at han skulde dem saa forlede.

Det Kapel de brøde neder i Grund, det siger jeg eder i demne Stund. 
Ogsaa ved Aarup siges at have været et Kapel, der maaske fik samme Skæbne.

Den eneste Sognekirke, som nedreves efter Kirkespaltningen, var den i Bjerndrup. Gregorius og Frans v. Ahlefeld, de to Brodre paa Søgaard (1559) kunde ellers ikke forliges; men derover blev de dog enige: at nedbryde Kirk?n i Bjerndrup.

Demnach mit Franz dem Bruder sein

christlich bedacht und geworden ein, zu machen von Kirchspielen zwein

Berndorff und Klypleff ein gemein.

Kirkens Bygning spredtes for alle Vinde. Der, hvor den stod, ligger nu en smuk og fredelig Bondegaard. I lange Tider anede ingen af dens Beboere eller af Byens Folk, at der laa en gammel Kirkegaard med Hundreder af hensmuldrede Lig under Stuegulvene. De døde har lært at tie. Og dog laa mange af dem med saa lidt Jord over sig, at de ved Midnatstide maatte kunne hviske de sovende noget i Øret, mens de laa i deres Senge. En Mængde Hovedskaller og andre Knogler er nu ved indendørs Arbejder paa Gaarden kommet for Dagens Lys for atter at gemmes i Stilhed et andet og mere passende Sted. Men undres maa man, at den mundtlige Overlevering er saa fattig som den er.

Hvor den forsvundne Kirke har ligget, hvordan den saa ud, hvor stor Kirkegaarden var og hvem der var begravet paa den - ingen har hørt noget derom. Mæudene i Landsbyer plejer at have travlt med mange Ting, ogsaa med at fortælle Historie fra Slægt til Slægt. Men Historien om Præsterne, der engang prædikede i Bjerndrup Kirke, om Klokkerne, der ringede ud over Byen og Marken, om Fonten ,hvori Børnene blev døbte, om Menighedens Skæbne - alt dette er vejret bort af Vinden. Saa ringe en Plads havde denne Kirke i Menneskenes Tanker og i Slægtens Hukommelse.

Og de døde tier. 